\title{
Simultaneous Mutations in the CLCNKB and SLC12A3 Genes in Two Siblings with Phenotypic Heterogeneity in Classic Bartter Syndrome
}

\author{
ALBERTO BETTINELLI, NICOLO BORSA, MARIE-LOUISE SYREN, CAMILLA MATTIELLO, \\ DOMENICO COVIELLO, ALBERTO EDEFONTI, MARISA GIANI, MAURIZIO TRAVI, \\ AND SILVANA TEDESCHI
}

\begin{abstract}
Department of Pediatrics [A.B.], San Leopoldo Mandic Hospital, 23807 Merate LC, Italy; Laboratory of Medical Genetics [N.B., C.M., D.C., M.T., S.T.], Department of Nephrology and Dialysis [A.E., M.G.], Fondazione IRCCS Ospedale Maggiore Policlinico, Mangiagalli e Regina Elena, 20122 Milano, Italy; Department of Pediatrics and Neonatology [M.L.S.], University of Milan, 20122 Milano, Italy
\end{abstract}

\begin{abstract}
Two siblings (brother and sister) with renal tubular hypokalemic alkalosis underwent clinical, biochemical and molecular investigations. Although the biochemical findings were similar (including hypokalemia, metabolic alkalosis, hyperreninemia, hyperaldosteronism and normal blood pressure), the clinical findings were different: the boy, who also presented syndromic signs, developed glomerular proteinuria and renal biopsy revealed focal segmental glomerular sclerosis; the girl showed the typical signs of classic Bartter syndrome. As described in a previous paper, a heterozygous mutation (frameshift 2534delT) was demonstrated in the gene encoding the thiazide-sensitive $\mathrm{NaCl}$ co-transporter (SLC12A3) of the distal convoluted tubule; the second molecular analysis revealed a compound heterozygous mutation (A61D/V149E) in the CLCNKB chloride channel gene in both subjects, inherited in trans from the parents. The
\end{abstract}

\section{ABSTRACT}

children were finally diagnosed as having classic Bartter syndrome. These cases represent the first report of the simultaneous presence of heterozygous and compound heterozygous mutations in the SLC12A3 and CLCNKB genes, both of which are involved in renal salt losing tubulopathies, and confirm previous observations regarding classic Bartter syndrome phenotype variability in the same kindred. (Pediatr Res 58: 1269-1273, 2005)

\section{Abbreviations}

cBS, classic Bartter syndrome

CLCNKB gene, chloride channel $\mathrm{ClC}-\mathrm{Kb}$ gene

FSGS, focal segmental glomerular sclerosis

GS, Gitelman syndrome

SLC12A3 gene, thiazide-sensitive $\mathrm{Na}-\mathrm{Cl}$ co-transporter gene SSCP, single strand conformation polymorphism
Bartter syndromes are inherited disorders characterized by hypokalemia, metabolic alkalosis, hyperreninemic-hyperaldosteronism and renal salt wasting in the presence of normal blood pressure that have at least three different phenotypes: a) antenatal Bartter syndrome (aBS) [OMIM 241200 and 601678] that is characterized by polyhydramnios, premature delivery, a failure to thrive, hypercalciuria and nephrocalcinosis (1), and may be caused by genetic variants in the genes encoding the luminal $\mathrm{Na}-\mathrm{K}-2 \mathrm{Cl}$ co-transporter (2) and the ROMK potassium channel $(3)$; b) the Bartter syndrome associated with sensorineural deafness [OMIM 602522] (4), in which the defects reside in the BSND gene (5); and c) classic Bartter syndrome (cBS) [OMIM 607364] which usually onsets in the first year of life.

Received January 19, 2005; accepted June 8, 2005.

Correspondence: Alberto Bettinelli, M.D., Department of Pediatrics, Ospedale San Leopoldo Mandic Hospital, Largo Mandic 1, 23807 Merate LC, Italy; email: abettinelli@ ospedale.Lecco.it

DOI: 10.1203/01.pdr.0000185267.95466.41
The main findings in cBS are a failure to thrive and marked salt wasting, and there may be nephrocalcinosis and hypercalciuria (6). The causative mutations are located in the CLCNKB gene encoding the basolateral chloride channel ( $\mathrm{ClC}-\mathrm{Kb})(6,7)$, which is located in the thick ascending limb of Henle's loop (TAL) and the distal tubule (DCT) (7). The characteristics of cBS are similar to those observed during combined thiazide and furosemide treatments (8).

Gitelman syndrome (GS) [OMIM 263800] is a different form of inherited hypokalemic metabolic alkalosis that usually onsets during childhood but may also emerge in adult life (9). It is characterized by hypomagnesemia and hypocalciuria, muscle weakness and tetanic crises, and its phenotype is due to mutations in the gene encoding the thiazide-sensitive $\mathrm{NaCl}$ co-transporter (SLC12A3) expressed in the DCT $(10,11)$. Unlike cBS, GS resembles the effect of long-term thiazide administration alone (8).

The overlapping biochemical and clinical features of $\mathrm{cBS}$ and $\mathrm{aBS}$, and those of $\mathrm{cBS}$ and GS, were first described by 
Konrad (6) and Peters (12). Jeck subsequently reported three unrelated patients with CLCNKB gene mutations and a phenotype transition from cBS to GS (13), and Zelikovic demonstrated the simultaneous presence of both cBS and GS phenotypes in a wide sibship carrying the same CLCNKB mutation (14). However, the simultaneous presence of SLC12A3 and CLCNKB gene mutations has never been reported.

We here describe the case of two siblings (brother and sister) whose first symptoms appeared in infancy and childhood. The boy had initially been diagnosed as having GS and the mutation analysis performed at the time identified a single frameshift mutation in the SLC12A3 gene (15); clinical evidence of the cBS phenotype was subsequently found in his younger sister, who also carried the isolated GS mutation. We therefore investigated the CLCNKB gene by means of direct DNA sequencing, and identified two previously undetected variants in both children.

\section{METHODS}

Subjects. The study was approved by our local Ethics Committee, and written informed consent was obtained from the parents of the patients.

The two siblings studied, brother and sister, were 19 and 6 y old, respectively, at the last clinical control. The first $13.2 \mathrm{y}$ of follow-up of the brother have been previously described (15). In brief, he had been diagnosed as having a renal tubular disease characterized by hypokalemia, metabolic alkalosis, hyperaldosteronism, hyperreninemia and normal blood pressure. Calciuria was in the normal range for his age, as were serum magnesium levels in more than half of the determinations. No proteinuria was detected. In his first years of life, he had speech problems, an uncertain gait and difficulty in making finger movements. His karyotype was normal $(46, \mathrm{XY})$ and a search for a fragile $\mathrm{X}$ chromosome was negative.

He started receiving indomethacin $\left(2 \mathrm{mg} \cdot \mathrm{Kg}^{-1} \cdot \mathrm{d}^{-1}\right)$ when he was $6.3 \mathrm{y}$ old. Further investigations revealed growth hormone deficiency, delayed vasopressin secretion and empty sella, and he was treated with recombinant growth hormone until the age of $7.2 \mathrm{y}$. Proteinuria $\left(1.5 \mathrm{~g} \cdot \mathrm{d}^{-1}\right)$ was detected when he was aged $10 \mathrm{y}$, and indomethacin was replaced by enalapril $(0.5$ $\left.\mathrm{mg} \cdot \mathrm{Kg}^{-1} \cdot \mathrm{d}^{-1}\right)$

Molecular variants in the aBS- (SLC12A1 and KCNJ1), CLCNKB and SLC12A3 genes had been sought by means of single-strand conformation polymorphism (SSCP) analysis: no mutations were found in the first three, but a single novel heterozygous mutation (a 1-bp deletion) was identified at position 2534 in exon 21 of the SLC12A3 gene. Although only a single mutation had been detected, it was considered pathogenetic and led to the diagnosis of GS (15).

During the first three months after the introduction of enalapril (when he was $13.4 \mathrm{y}$ ), his proteinuria declined, but subsequently increased to a maximum of $2.14 \mathrm{~g} \cdot \mathrm{d}^{-1}$.

When the boy was $15 \mathrm{y}$ old, he underwent a renal biopsy and the specimen was examined by means of light, immunofluorescence and electron microscopy. The treatment with enalapril was continued, and there was a progressive reduction in proteinuria.

At his last clinical evaluation (when he was 19 y old), plasma potassium was $3.5 \mathrm{mM}$, associated with high plasma renin levels $(>320 \mathrm{pg} / \mathrm{mL})$ and normal values of aldosterone $(129 \mathrm{pg} / \mathrm{mL})$. Proteinuria was $0.26 \mathrm{~g} \cdot \mathrm{d}^{-1}$. Plasma creatinine was in the normal range $(0.84 \mathrm{mg} \%)$.

The female was born at term after an uncomplicated pregnancy with a birth weight of $3,950 \mathrm{~g}$. During the pregnancy, a DNA evaluation of coriali villi showed that the fetus had inherited the same unique variant on the SLC12A3 gene as her brother, but the parents decided to continue the pregnancy.

At the age of two months, she presented weight deficiency $\left(<3^{\text {rd }}\right.$ percentile). The main biochemical data were: plasma potassium $2.5 \mathrm{mM}$, chloride 90 $\mathrm{mM}$ and sodium $134 \mathrm{mM}$; plasma magnesium was normal $(0.8 \mathrm{mM})$, and bicarbonate was high $(>30 \mathrm{mM})$. Azotemia $(54 \mathrm{mg} \%)$ was at the upper normal limit, and plasma creatinine was $0.5 \mathrm{mg} \%$. These data were subsequently confirmed. Hyperreninemia $(259 \mathrm{pg} / \mathrm{mL}$ versus reference values of $<33$ $\mathrm{pg} / \mathrm{mL})$ and hyperaldosteronism $(436 \mathrm{pg} / \mathrm{mL}$ versus reference values of $<300$ $\mathrm{pg} / \mathrm{mL}$ ) were associated with normal blood pressure $(80 / 50 \mathrm{~mm} \mathrm{Hg})$. Urinary calcium excretion was normal for her age (a molar urinary calcium/creatinine ratio of 0.53$)$, as was the level of plasma magnesium $(0.92 \mathrm{mM})$.
During her first years of life, she was treated with oral $\mathrm{KCl}$ and $\mathrm{NaCl}$ supplements alone, but indomethacin $\left(2-2.5 \mathrm{mg} \cdot \mathrm{Kg}^{-1} \cdot \mathrm{d}^{-1}\right)$ was introduced because of growth delay.

At her last clinical examination (when she was six years old), her weight was $16.3 \mathrm{~kg}\left(8^{\text {th }}\right.$ percentile $)$ and her height was $107 \mathrm{~cm}\left(15^{\text {th }}\right.$ percentile $)$; during indomethacin treatment, her plasma potassium was $3.1 \mathrm{mM}$, associated with persistently high plasma aldosterone $(584 \mathrm{pg} / \mathrm{mL})$ and renin levels $(165$ $\mathrm{pg} / \mathrm{mL}$ ). No proteinuria was detected. During the follow-up period, plasma magnesium was low in 3/10 determinations; hypocalciuria was also present in half of the determinations as the girl was treated with indomethacin.

Protocol. As the girl's phenotype was more typical of cBS than GS, she, her parents, and then her brother underwent molecular evaluation by means of direct CLCNKB gene sequencing.

Genomic DNA was extracted from peripheral blood cells using standard methods. All of the coding sequences of the CLCNKB and the SLC12A3 genes and their intron-exon boundaries were amplified by means of polymerase chain reaction (PCR) using a primer set and conditions based on the data of Simon (7) and Mastroianni (11), except for exon 1 of the CLCNKB gene (based on Konrad) (6). The PCR product was used as the template in a cycle sequencing reaction to obtain the forward and reverse strands of the amplified products, and single filaments were sequenced on an ABI PRISM 3100 Genetic Analyzer (Applied Biosystem).

\section{RESULTS}

Renal biopsy of the male sibling. Light microscopy showed eleven glomeruli with an enlarged mesangial matrix and no signs of proliferation. Two glomeruli showed focal segmental sclerosis characterized by cellular lesions such as collapse of the glomerular capillaries and adesions of the glomerular tuft with swollen and vacuolated podocytes (Fig. 1).

Hyperplasia of the juxtaglomerular apparatus was also observed. The interstitium, tubules and vessels were unremarkable.

Immunofluorescence revealed mild staining for mesangial C1q.

Molecular genetics. Due to the lack of a second mutation in the SLC12A3 gene, we analyzed the CLCNKB gene by means of direct DNA sequencing, and a compound heterozygous A61D/V149E mutation was observed in both patients: the alanine residue replaced by an aspartic acid in A61D (216C $>$ A) (Fig. 2), and the valine by glutamic acid in V149E $(480 \mathrm{~T}>\mathrm{A})$. These heterozygous missense mutations were inherited in trans from the parents: the mother presented both the

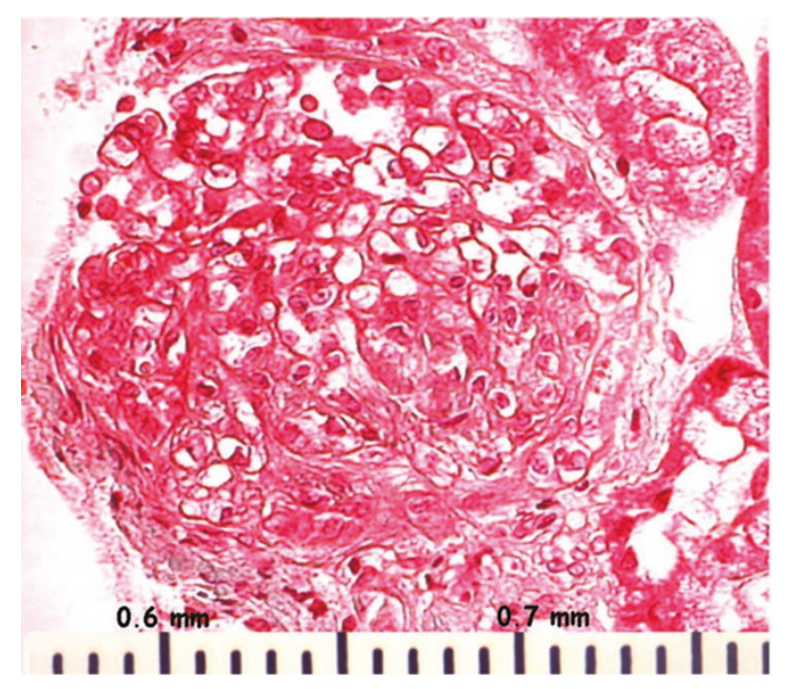

Figure 1. Light microscopy image showing a glomerulus with early stage of focal segmental sclerosis (31) (magnification 40× - Masson's trichrome stain). 


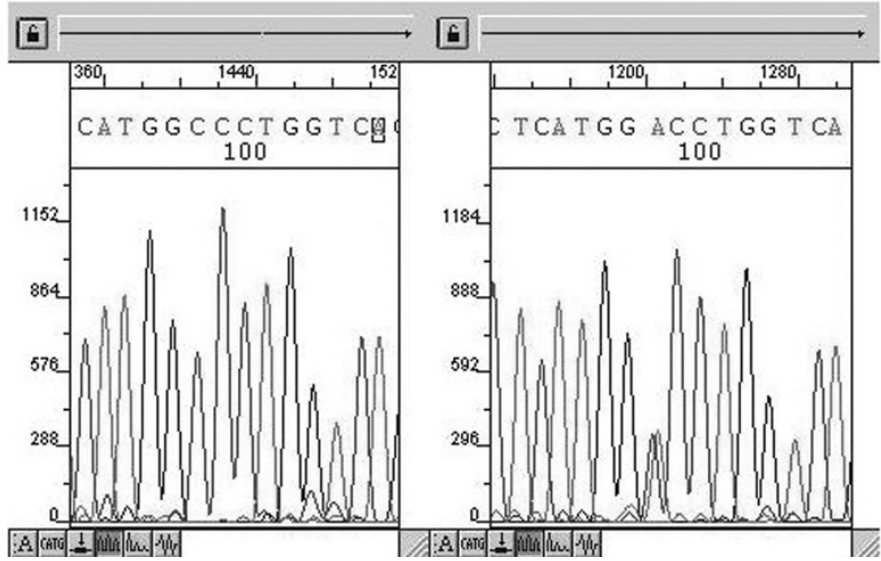

Figure 2. Partial sequence of exon 2 of the CLCNKB gene showing the wild type (left) and the A61D mutation (right).

A61D in the CLCNKB gene and the 2534delT in the SLC12A3 gene. None of the three detected variants was observed in 100 chromosomes in the Italian population. The heterozygous R904Q variant and three common heterozygous polymorphisms - S628S, IVS24(-17) and IVS25(+13) - were detected in the SLC12A3 gene in both siblings and the father, but not in the mother, thus demonstrating the same paternal allele inheritance of both children (Fig. 3).

\section{DISCUSSION}

This is the first description of the simultaneous presence of SLC12A3 and CLCNKB gene mutations. The 2534delT frameshift mutation in the SLC12A3 gene [erroneously named in our previous report (15)] introduces a stop codon at amino acid 865, and generates a truncated protein that lacks the carboxy-terminus with its four potential phosphorylation sites in the intracytoplasmatic region. This heterozygous pathogenic mutation was found in both children and the mother. The R904Q variant detected on the SLC12A3 gene in both children

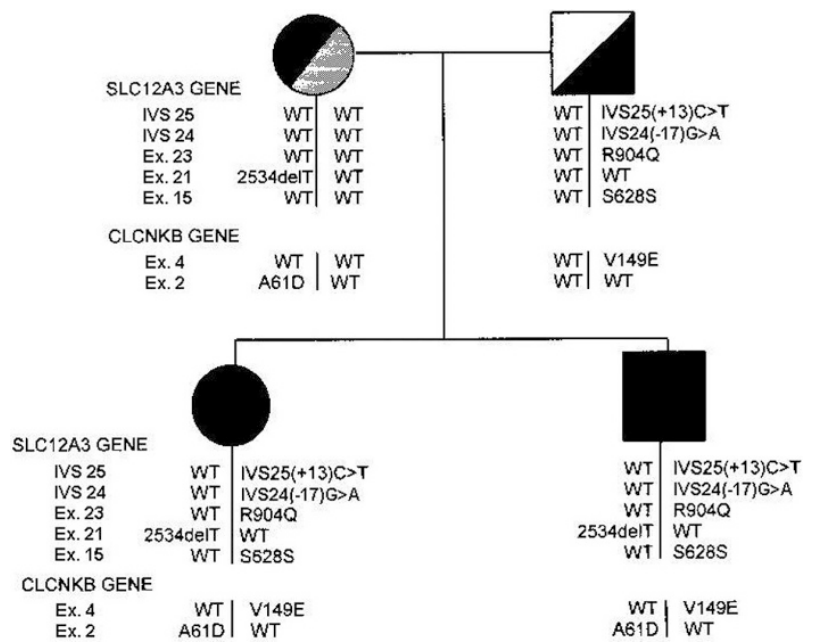

Figure 3. Pedigree with schematic representation of the CLCNKB and SLC12A3 haplotype inheritance in the parents and their sibship. $\square$ Male and female afflicted with Bartter III syndrome and heterozygotes for SLC12A3 mutation. Heterozygote for CLCNKB and SLC12A3 mutations. Z Heterozygote for CLCNKB mutation. was inherited from their father. We have found this variant in $9 \%$ of the Italian control population (16) and, as also reported by others (17), it does not seem to be involved in GS. However, it is worth mentioning that, in the latter study, homozygous R904Q was more frequent in hypertensive patients than normotensive subjects. Another study of diabetic patients found that R904Q is a protective factor against the development of nephropathy (18), but its role in the context of our patients (if any) is not clear.

The presence of a heterozygous mutation is obviously insufficient for a final diagnosis of a recessively inherited disease. The fact that the second mutation in the SLC12A3 gene could not be identified at the first molecular analysis, was explained by the lack of sensitivity of the mutation detection system, the SSCP analysis, or the potential localization of mutational events in the extra-exon sequences that were not studied. The decision to concentrate on the CLCNKB gene was crucially due to the fact that the girl presented with the cBS phenotype. The compound heterozygous A61D/V149E mutation was subsequently detected in the CLCNKB gene in the siblings, and its parental origin was confirmed. Alanine 61 and valine 149 are highly conserved amino acids in the $\mathrm{ClC}$ chloride channels among the species, which indicates their essential role for the functional expression of the $\mathrm{ClC}-\mathrm{Kb}$ channel (19).

We hypothesize that some of the observed abnormalities in the two patients may be due to the characteristic pattern of $\mathrm{ClC}-\mathrm{Kb}$ expression. Expressed in both TAL and DCT, $\mathrm{ClC}-\mathrm{Kb}$ may partially explain the overlapping biochemical abnormalities of GS and cBS, such as hypomagnesemia and hypocalciuria. Reinalter et al. (8) explained the clinical and pathophysiology findings in patients with mutations in the CLC-Kb chloride channel in terms of the combination of the pharmacoprofiles of thiazides (typical of GS) and the loop diuretic furosemide. Our patients presented some plasma magnesium values below the reference limits, although hypomagnesemia is usually present in almost all GS patients. We have no further explanation for the pathogenesis of hypomagnesemia in cBS, or the role played by the combined defects in two specific transport proteins (ClC-Kb and NCCT) in our patients' electrolyte and mineral abnormalities. Furthermore, no cell study of mutation expression was performed.

Many authors have reported connections between cBS and GS: Konrad (6) observed overlapping phenotypes in patients with SLC12A3 or CLCNKB gene mutations, and Jeck (13) described three unrelated patients with a mixed BartterGitelman phenotype whose genetic variants resided in the CLCNKB gene. Recently, Schlingmann (20) has reported a case with mutations in two genes involved in renal salt transport: a child with renal salt losing tubulopathy and deafness did not show defects on the Barttin gene, but had homozygous mutations on both the $\mathrm{ClC}-\mathrm{Ka}$ and $-\mathrm{Kb}$ chloride channels. Fukuyama et al. (21) hypothesized that GS and BS patients frequently show mutations in more than one of the involved transporter genes but, in our view, the patients described in their paper must be considered as polymorphism carriers as Jeck et al. (22) subsequently demonstrated that three of the four amino acid variants were common sequence variations without any functional effect in an expression system study. 
Furthermore, the fourth variant (V524I) was identified in a case of ours: the mother of a cBS patient with a homozygous deletion of the entire CLCNKB gene carried the heterozygous deletion on her first allele and the V524I variant on the second, without presenting any biochemical or clinical abnormalities (data not shown). Finally, Zelikovic (14) reported a large bedouin pedigree with a common homozygous missense mutation in the CLCNKB gene and the concomitant presence in the kindred of Gitelman and classic Bartter phenotypes. Like Zelikovic, who could not find a reason for the phenotypic variability among his twelve patients, we can only formulate some hypotheses: the basolateral chloride secretion impaired by CLCNKB gene mutations could functionally cooperate with and/or be compensated for by alternative routes of chloride efflux, such as the passive chloride diffusion mediated by the CLCNKA gene, the $\mathrm{K}-\mathrm{Cl}$ co-transporter, the cystic fibrosis transmembrane regulator (CFTR) and/or the ClC-5 voltagegated chloride channel. In addition to all of these alternative cellular mechanisms, genotype diversity might also play a role: the different phenotypes observed in renal tubulopathies may be caused by interactions with still unknown modifier genes, as is seen in other diseases in which genotype-phenotype correlations do not fully explain the individual clinical presentation (i.e., cystic fibrosis).

At least for the first years of life (the girl is still only six years old), the biochemical characteristics of our two patients were similar. The presence of growth hormone deficiency and mental retardation in the boy may be explained by other defects in different genes. In the case of our siblings, individual susceptibility to drug therapies should also be considered as it is possible that the girl may subsequently develop proteinuria and focal segmental glomerular sclerosis (for example) like her brother.

The second interesting point of our study is the evidence of focal segmental glomerular sclerosis (FSGS) in the boy. At the time of our previous paper (15), he presented proteinuria but had not undergone renal biopsy. The presence of proteinuria in patients with tubular disorders has been explained on the basis of a possible role of indomethacin and other nonsteroidal drugs $(23,24)$ and although still in the nephrotic range, his proteinuria improved after the withdrawal of the drug. However, even though it decreased to $0.15 \mathrm{~g} / \mathrm{d}$ after indomethacin withdrawal, it had increased to a maximum of $2.14 \mathrm{~g} / \mathrm{d}$ three months later: our data therefore do not support the hypothesis regarding antiprostaglandin drugs. Furthermore, two recent papers regarding possible side effects in patients receiving long-term indomethacin treatment made no mention of proteinuria $(25,26)$.

The presence of FSGS in patients with Bartter syndrome has been previously reported at least twice: in a 51-y-old woman (27) and a 15-y-old Indian girl (28). One possible explanation of the FSGS is that stimulation of the renin-angiotensin system with increased angiotensin II and the production of transforming growth factor-beta is involved in the sclerotic renal lesions associated with various glomerular diseases including FSGS (28). Alternatively, there is a large body of evidence indicating that aldosterone per se may mediate progressive renal disease (29). In this regard, it is interesting to note that aldosterone level was normal and proteinuria was low $(0.26 \mathrm{~g} / \mathrm{d})$ at the last clinical examination. On the other hand, the reduction in proteinuria may also be due to the long-term use of enalapril (30) as the sister presented persistently high levels of both renin and aldosterone, but no proteinuria was detected. In the light of these observations, the possible pathogenesis of FSGS in patients with Bartter syndrome needs further evaluation.

In conclusion, our study suggests that molecular investigations are very important for the final diagnosis of hypokalemic patients with suspected Bartter/Gitelman syndrome and an atypical phenotype, and are required for the demonstration of homozygous or compound heterozygous findings. Moreover, further studies are necessary to explain whether the simultaneous presence of mutations in both the SLC12A3 and CLCNKB genes has any pathologic significance. Finally, our report confirms phenotype heterogeneity in the same family of identical CLCNKB mutations, including the possibility of developing glomerular proteinuria and FSGS.

Acknowledgment. We would like to thank the "Associazione per il Bambino Nefropatico" for its financial support.

\section{REFERENCES}

1. Seyberth HW, Rascher W, Schweer H, Kuhl PG, Mehls O, Scharer K 1985 Congenital hypokalemia with hypercalciuria in preterm infants: a hyperprostaglandinuric tubular syndrome different from Bartter syndrome. J Pediatr 107:694-701

2. Simon DB, Karet FE, Hamdan JM, DiPietro A, Sanjad SA, Lifton RP 1996 Bartter's syndrome hypokalaemic alkalosis with hypercalciuria, is caused by mutations in the Na-K-2Cl cotransporter NKCC2. Nat Genet 13:183-88

3. Simon DB, Karet FE, Rodriguez-Soriano J, Hamdan JH, DiPietro A, Trachtman H, Sanjad SA, Lifton RP 1996 Genetic heterogeneity of Bartter's syndrome revealed by mutations in the K+ channel ROMK. Nat Genet 14:152-156

4. Brennan TM, Landau D, Shalev H, Lamb F, Schutte BC, Walder RY, Mark AL, Carmi R, Sheffield VC 1998 Linkage of infantile Bartter syndrome with sensorineural deafness to chromosome 1p. Am J Hum Genet 62:355-361

5. Birkenhager R, Otto E, Schurmann MJ, Vollmer M, Ruf EM, Maier-Lutz I, Beekmann F, Fekete A, Omran H, Feldmann D, Milford DV, Jeck N, Konrad M, Landau D, Knoers NV, Antignac C, Sudbrak R, Kispert A, Hildebrandt F 2001 Mutation of BSND causes Bartter syndrome with sensorineural deafness and kidney failure. Nat Genet 29:310-314

6. Konrad M, Vollmer M, Lemmink HH, Lambertus P, van den Heuvel LP, Jeck N Vargas-Poussou R, Lakings A, Ruf R, Deschenes G, Antignac C, Guay-Woodford L, Knoers NV, Seyberth HW, Feldmann D, Hildebrandt F 2000 Mutations in the chloride channel gene CLCNKB as a cause of classic Bartter syndrome. J Am Soc Nephrol 11:1449-1459

7. Simon DB, Bindra RS, Mansfield TA, Nelson-Williams C, Mendonca E, Stone R, Schurman S, Nayir A, Alpay H, Bakkaloglu A, Rodriguez-Soriano J, Morales JM, Sanjad SA, Taylor CM, Pilz D, Brem A, Trachtman H, Griswold W, Richard GA, John E, Lifton RP 1997 Mutations in the chloride channel gene, CLCNKB, cause Bartter's syndrome type III. Nature Genet 17:171-178

8. Reinalter SC, Jeck N, Peters M, Seyberth HW 2004 Pharmacotyping of hypokalaemic salt-losing tubular disorders. Acta Physiol Scand 181:513-521

9. Gitelman HJ, Graham JB, Welt LG 1966 A new familial disorder characterized by hypokalemia and hypomagnesemia. Trans Assoc Am Physicians 79:221-235

10. Simon DB, Nelson-Williams C, Bia MJ, Ellison D, Karet FE, Molina AM, Vaara I, Iwata F, Cushner HM, Koolen M, Gainza FJ, Gitleman HJ, Lifton RP 1996 Gitelman's variant of Bartter's syndrome, inherited hypokalemic alkalosis, is caused by mutations in the thiazide-sensitive Na-Cl cotransporter. Nat Genet 12:24-30

11. Mastroianni N, Bettinelli A, Bianchetti M, Colussi G, De Fusco M, Sereni F, Ballabio A, Casari G 1996 Novel molecular variants of the $\mathrm{Na}-\mathrm{Cl}$ cotransporter gene are responsible for Gitelman syndrome. Am J Hum Genet 59:1019-1026

12. Peters M, Jeck N, Reinalter S, Leonhardt A, Tonshoff B, Klaus GG, Konrad M, Seyberth HW 2002 Clinical presentation of genetically defined patients with hypokalemic salt-losing tubulopathies. Am J Med 112:183-190

13. Jeck N, Konrad M, Peters M, Weber S, Bonzel KE, Seyberth HW 2000 Mutations in the chloride channel gene, CLCNKB, leading to a mixed Bartter-Gitelman phenotype. Pediatr Res 48:754-758

14. Zelikovic I, Szargel R, Hawash A, Labay V, Hatib I, Cohen N, Nakhoul F 2003 A novel mutation in the chloride channel gene, CLCNKB, as a cause of Gitelman and Bartter syndromes. Kidney Int 63:24-32

15. Bettinelli A, Rusconi R, Ciarmatori S, Righini V, Zammarchi E, Donati MA, Isimbaldi C, Bevilacqua M, Cesareo L, Tedeschi S, Garavaglia R, Casari G 1999 Gitelman disease associated with growth hormone deficiency, disturbances in vaso- 
pressin secretion and empty sella: a new hereditary renal tubular-pituitary sindrome? Pediatr Res 46:232-238

16. Syrén ML, Tedeschi S, Cesareo L, Bellantuono R, Colussi G, Procaccio M, Ali A, Domenici R, Malberti F, Sprocati M, Sacco M, Miglietti N, Edefonti A, Sereni F, Casari G, Coviello DA, Bettinelli A 2002 Identification of fifteen novel mutations in the SLC12A3 gene encoding the $\mathrm{Na}-\mathrm{Cl} \mathrm{Co}$-transporter in Italian patients with Gitelman syndrome. Hum Mutat 20, Issue 1:78-78; web page http://dx.doi.org/ 10.1002/humen. 9045

17. Melander O, Orho-Melander M, Bengtsson K, Lindblad U, Rastam L, Groop L, Hulthen UL 2000 Genetic variants of thiazide-sensitive NaCl-cotransporter in Gitelman's syndrome and primary hypertension. Hypertension 36:389-394

18. Tanaka N, Babazono T, Saito S, Sekine A, Tsunoda T, Haneda M, Tanaka Y, Fujioka T, Kaku K, Kawamori R, Kikkawa R, Iwamoto Y, Nakamura Y, Maeda S 2003 Association of solute carrier family 12 (sodium/chloride) member 3 with diabetic nephropathy, identified by genome-wide analyses of single nucleotide polymorphisms. Diabetes 52:2848-2853

19. Kieferle S, Fong P, Bens M, Vandewalle A, Jentsch T 1994 Two highly homologous members of the $\mathrm{ClC}$ chloride channel family in both rat and human kidney. Proc Natl Acad Sci USA 91:6943-6947

20. Schlingmann KP, Konrad M, Jeck N, Waldegger P, Reinalter SC, Holder M, Seyberth HW, Waldegger S 2004 Salt wasting and deafness resulting from mutations in two chloride channels. N Engl J Med 350:1314-1319

21. Fukuyama S, Okudaira S, Yamazato S, Yamazato M, Ohta T 2003 Analysis of renal tubular electrolyte transporter genes in seven patients with hypokalemic metabolic alkalosis. Kidney Int 64:808-816
22. Jeck N, Waldegger P, Doroszewicz J, Seyberth H, Waldegger S 2004 A common sequence variation of the CLCNKB gene strongly activates $\mathrm{ClC}-\mathrm{Kb}$ chloride channel activity. Kidney Int 65:190-197

23. Clive DM, Stoff JS 1984 Renal syndromes associated with nonsteroidal antiinflammatory drugs. N Engl J Med 310:563-572

24. Lindsley CB, Warady BA 1990 Nonsteroidal antiinflammatory drugs. Renal Toxicity. Review of pediatric issues. Clin Pediatr 29:10-13

25. Reinalter SC, Grone HJ, Konrad M, Seyberth HW, Klaus G 2001 Evaluation of long-term treatment with indomethacin in hereditary hypokalemic salt-losing tubulopathies. J Pediatr 139:398-406

26. Vaisbich MH, Fujimura MD, Koch VH 2004 Bartter syndrome: benefits and side effects of long-term treatment. Pediatr Nephrol 19:858-863

27. Blethen SL, Van Wyk JJ, Lorentz WB, Jennette JC 1985 Reversal of Bartter's syndrome by renal transplantation in a child with focal, segmental glomerular sclerosis. Am J Med Sci 289:31-36

28. Su IH, Frank R, Gauthier BG, Valderrama E, Simon DB, Lifton RP, Trachtman 2000 Bartter syndrome and focal segmental glomerulosclerosis: a possible link between two diseases. Pediatr Nephrol 14:970-972.

29. Hollenberg NK 2004 Aldosterone in the development and progression of renal injury. Kidney Int 66:1-9

30. White CT, Macpherson CF, Hurley RM, Matsell DG 2003 Antiproteinuric effects of enalapril and losartan: a pilot study. Pediatr Nephrol 18:1038-1043

31. Ohtaka A, Ootaka T, Sato H, Ito S 2002 Phenotypic change of glomerular podocytes in primary focal segmental glomerulosclerosis: developmental paradigm? Nephrol Dial Transplant 17:11-15 